\title{
Management of Gastric Neuroendocrine Tumors
}

\author{
Gastrik Nöroendokrin Tümörlerin Yönetimi
}

\begin{abstract}
Aim: The widespread use of endoscopy has led to a marked increase in the reported incidence and prevalence of gastric neuroendocrine tumors (NETs). In this study, we aimed to investigate these rare and poorly understood tumors in patients from a single center.

Materials and Methods: We retrospectively reviewed the medical records of patients who were treated with a diagnosis of gastric NET between January 2010 and December 2018. Data on patient demographic characteristics, diagnostic work-up, endoscopic and surgical treatment patterns, histopathological features, and outcome parameters were documented. The Ki-67 proliferation index, mitosis ratio, and immunohistochemical staining with chromogranin A and synaptophysin were evaluated by histopathological examination.

Results: The study included 17 patients ( 9 males, 8 females), with a mean age of 61.7 years. Nine patients had a tumor located in the fundus, 5 in the antrum, and 3 in the corpus. Histopathological evaluation diagnosed 6 well-differentiated type I NETs and 11 poorly differentiated type III NETs. Seven (41\%) patients underwent surgery (with adjuvant chemotherapy when indicated), 6 (35\%) only endoscopic treatment, and 4 only chemotherapy. Seven (41\%) of the 17 patients had distant metastases at the time of diagnosis, with the liver being the most commonly involved organ.

Discussion and Conclusion: Gastric NETs are categorized into three groups according to mitotic activity and the Ki-67 index. Data on serum gastrin levels and endoscopic and radiological work-up are required for this categorization. Treatment approach varies according to the type and stage of the disease.
\end{abstract}

Keywords: endoscopy; gastrin; Ki-67 index; neuroendocrine tumor

\section{Öz}

Amaç: Endoskopinin yaygın kullanımı, gastrik nöroendokrin tümörler (NET) için bildirilen insidans ve prevalansta belirgin bir artıșa yol açmıștır. Çalıșmamızda bu nadir ve az anlașıımıs tümörleri tek bir merkezden hastalarda incelemek amaçlanmıștır.

Gereç ve Yöntemler: Ocak 2010-Aralık 2018 döneminde gastrik NET tanısı konarak tedavi edilen hastaların tıbbi kayıtları retrospektif olarak değerlendirildi. Demografik hasta özelliklerine, tanı çalıșmalarına, endoskopik ve cerrahi tedavi yöntemlerine, histopatolojik özelliklere ve sonuç parametrelerine dair veriler kaydedildi. Ki-67 proliferasyon indeksi, mitoz oranı, ve de kromogranin A ve sinaptofizin ile immünohistokimyasal boyanma, histopatolojik incelemeyle değerlendirildi.

Bulgular: Çalıșmaya yaș ortalaması 61,7 yıl olan 17 hasta ( 9 erkek, 8 kadın) dahil edildi. Tümör 9 hastada fundus, 5 hastada antrum, 3 hastada korpus yerleșimliydi. Histopatolojik değerlendirme tanıları, 6 iyi diferansiye tip I NET ve 11 kötü diferansiye tip III NET seklindeydi. Yedi (\%41) hastada (gerektiğinde adjuvan kemoterapiyle beraber) cerrahi, 6 (\%35) hastada sadece endoskopik tedavi ve 4 hastada sadece kemoterapi uygulandı. On yedi (\%41) hastanın 7'sinde tanı anında uzak metastaz mevcuttu ve karaciğer en sık metastaz görülen organdı.

Tartıșma ve Sonuç: Gastrik NET'ler mitotik aktivite ve Ki-67 indeksine göre üç gruba ayrılmaktadır. Bu ayrım için serum gastrin düzeyi verileri ile endoskopik ve radyolojik çalıșmalar gereklidir. Tedavi yaklașımı hastalığın tipine ve evresine göre değișir.

Anahtar Sözcükler: endoskopi; gastrin; Ki-67 indeksi; nöroendokrin tümör
Fatih Dasiran',
Ahmet Akbas $^{2}$

1 Department of Surgery, Faculty of Medicine, Gaziosmanpasa University

2 Department of Surgery, Bagcilar Training and Research Hospital

Received/Gelis : 11.02 .2020 Accepted/Kabul: 20.05.2020

DOI: 10.21673/anadoluklin.687259

Corresponding author/Yazıșma yazarı Fatih Dasiran

Sevki Erek Yerleșkesi, Gaziosmanpașa Üniversitesi Tıp Fakültesi, Genel Cerrahi, 60030 Tokat, Turkey

E-mail: fatihdasiran@yahoo.com

\section{ORCID}

Fatih Dasiran: 0000-0003-1358-0158 Ahmet Akbas: 0000-0002-6333-4919 


\section{INTRODUCTION}

The term carcinoid was first used in 1907 for tumors that exhibit a slower growth pattern and better prognosis compared to carcinomas. The first definition referred to small, multiple, invasive, slow-growing lesions surrounded by non-differentiated tissue with no capacity of metastasis (1). To date, many different definitions and classifications have been made for carcinoid tumors. In 2010, the World Health Organization (WHO) proposed a new classification because of the difficulties with the existing classifications, and the term carcinoid tumor was replaced by the expression "neuroendocrine tumor" (NET). This grading system of NETs was upgraded in 2017.

NETs constitute $0.5 \%$ of all malignancies (2). Although they can be seen in various parts of the body, they mostly originate from the gastrointestinal tract. Gastrointestinal NETs commonly originate from the ileum, appendix, and rectum $(3,4)$. NETs of the stomach are rare and comprise 0.3 to $1.7 \%$ of all gastric cancers (5). These tumors develop from enterochromaffin-like (ECL) cells in the gastric mucosa and are categorized into three types. Type I and II gastric NETs are associated with achlorhydria, ECL cell hyperplasia, and hypergastrinemia while type III is sporadic. Characteristic features of the NET subtypes are summarized in Table 1.

During the recent years, the reported incidence and prevalence of gastric NETs have been on the rise, due mostly to the increasingly widespread use of endoscopy. The treatment and prognosis in patients with NETs vary according to the degree of differentiation and tumor stage, with the prognosis often being better at earlier stages (6-8). Accordingly, in this study we aimed to investigate gastric NETs diagnosed and managed in a single center and increase awareness of these rare and poorly understood tumors.

\section{MATERIALS AND METHODS}

We retrospectively reviewed the medical records of patients who were treated with a diagnosis of gastric NET at the Gaziosmanpasa University Medical Faculty Hospital between January 2010 and December 2018. Patients under the age of 18 years were excluded. Data on patient demographic characteristics, diagnostic work- up, endoscopic and surgical treatment patterns, histopathological features, and outcome parameters were documented. The Ki-67 proliferation index, mitosis ratio, immunohistochemical staining with chromogranin A and synaptophysin were evaluated by histopathological examination. The tumor grading was done according to the WHO 2010 classification based on mitotic counts and the Ki-67 proliferation index, regardless of tumor size, extent and location (grade 1: well-differentiated, low-grade; grade 2: well-differentiated, intermediate grade; grade 3: poorly differentiated, high-grade). The follow-up data were obtained from the medical records and by telephone interviews.

\section{Study ethics}

The study protocol was approved by the Ethical Committee of the Gaziosmanpasa University (20-KAEK004).

\section{Statistical analysis}

Statistical analyses were performed by using the SPSS 20.0 software package. The Kaplan-Meier method was used for survival analysis. The significance of survivalrelated variables was assessed by Cox regression model. $\mathrm{p}<0.05$ was considered statistically significant.

\section{RESULTS}

Of the 17 patients included, 9 (53\%) were male and $8(47 \%)$ were female. The mean patient age was 61.7 (40-83) years. Six (35\%) patients had well-differentiated, low-grade tumors while $11(65 \%)$ had poorly differentiated, high-grade tumors. No well-differentiated intermediate-grade tumor was observed. Histopathological evaluation diagnosed 6 well-differentiated type I NETs and 11 poorly differentiated type III NETs.

Nine patients had a tumor located in the fundus, 5 in the antrum, and 3 in the corpus. In none of the patients the pylorus and cardia of the stomach were involved. All patients were symptomatic and the most common symptom was abdominal pain, followed by loss of appetite, nausea and vomiting, constipation, and diarrhea (Table 2).

Seven (41\%) patients underwent surgery with or without adjuvant chemotherapy, 6 (35\%) only endoscopic treatment, and 4 only chemotherapy. Seven 
Table 1. Characteristic features of the NET subtypes

\begin{tabular}{llllll}
\hline Type & $\begin{array}{l}\text { Incidence } \\
(\%)\end{array}$ & Endoscopy & Gastrin & pH & Metastasis potential \\
\hline I & 70 & Multiple, small, non-pedunculated & High & High & Low \\
\cline { 4 - 6 } II & 5 & polyps & High & Low & Moderate \\
\hline III & 25 & Solitary large lesions & Normal & Normal & High \\
\hline
\end{tabular}

Table 2. Symptoms observed at the time of diagnosis

\begin{tabular}{lll}
\hline Symptoms & $\mathrm{n}$ & $\%$ \\
\hline Abdominal pain & 12 & 71 \\
\hline Loss of appetite & 9 & 53 \\
\hline Nausea/vomiting & 8 & 47 \\
\hline Constipation & 6 & 35 \\
\hline Diarrhea & 5 & 29 \\
\hline Melena/haematochezia & 5 & 29 \\
\hline
\end{tabular}

(41\%) patients had distant metastases at the time of diagnosis, with the liver being the most commonly involved organ $(n=6)$. One patient had liver and bone metastases.

The mean follow-up was 41 months, with a 3-year survival rate of $71 \%$. The 3 -year overall survival rate was $83 \%$ for grade 1 tumors and $44 \%$ for grade 3 tumors, and the difference in overall survival was statistically significant $(\mathrm{p}<0.05)$. The 3 -year overall survival rate was $83 \%$ and only $33 \%$ for patients without and with distant metastasis at the time of diagnosis, respectively, and the difference between the two groups was statistically significant $(\mathrm{p}<0.05)$.

\section{DISCUSSION AND CONCLUSION}

Gastrointestinal NETs are a heterogeneous group of tumors originating from neuroendocrine cells of the gastrointestinal tract with different degrees of differentiation, slow growth rate, hormonal secretion when functional, and lower malignancy potential compared to epithelial tumors. While gastrointestinal NETs are commonly located in the ileum, appendix, and rectum, gastric NETs are rare (4). In a study using the National Cancer Institute Surveillance, Epidemiology, and Results program (1973-1997) data, 11,427 cases were analyzed and it was found that of all NETs $54.5 \%$ were gastrointestinal NETs, of which $7.2 \%$ originated from the stomach (9). The mean age was 60.9 years for the study sample, of which $54.2 \%$ were comprised of females. Similarly, in our study the mean patient age was 61.7 years, with a female percentage of $47.1 \%$.

Staging, tumor characteristics, and metastasis should be investigated in patients with NETs. Tumor size plays a decisive role in determining the treatment approach in type I NETs; no further examination is required for type I gastric NETs smaller than $1 \mathrm{~cm}$. Oneto- $2-\mathrm{cm}$ lesions should be evaluated by endoscopic ultrasound (EUS) and removed by endoscopic intervention if there is no muscularis propria invasion. For lesions larger than $2 \mathrm{~cm}$, metastasis work-up by computerized tomography (CT) or magnetic resonance imaging (MRI) is recommended $(10,11)$. There is not a consensus on the treatment of gastric NETs smaller than $1 \mathrm{~cm}$; close observation without any intervention, excision of all lesions by endoscopy or surgery, endoscopic excision for lesions less than 5 , and surgery for more than 5 lesions are all effective and accepted treatment modalities (12-15). Antrectomy and long-acting somatostatin analogues for the reduction of gastrin hormone secretion are also discussed $(16,17)$. After endoscopic excision of the lesions, annual endoscopic follow-up should be performed.

In patients with type I NETs, surgery should be the preferred treatment in case of tumor invasion of the submucosa or muscularis propria, metastasis, lesions larger than $2 \mathrm{~cm}$, and poor differentiation shown by histopathological examination. In our case series, histopathological evaluation diagnosed $6(35.2 \%)$ type I NETs in 5 females and 1 male whose mean age was 55.3 years. The tumor was located in the corpus in 2 and in the antrum in 4 of these patients. The tumor size was 1 to $2 \mathrm{~cm}$ for 1 corpus-located tumor and 2 antrum-located tumors. Preoperatively, the cases were first evaluated by EUS and muscularis propria invasion was ruled out. Histopathological examination after polypectomy revealed that the tumors were confined to the mucosa and did not invade the submucosa in these 3 patients. In the other 3 cases, the tumor 
size was less than $1 \mathrm{~cm}$ and endoscopic polypectomy was performed. All patients underwent an endoscopic check 6 months after the procedures and no recurrence was observed. Annual endoscopic follow-up was then recommended.

Unlike the case with type I NETs, observation without treatment is not possible in patients with type II gastric NETs. All detected lesions should be removed. Endoscopic resection is performed in localized lesions and surgical resection is performed in invasive or metastatic lesions. Also, EUS, CT, MRI and octreotide scintigraphy are recommended for the localization of the underlying gastrinoma. Gastrinoma can be localized by scintigraphy and EUS in almost two-thirds of gastrinoma cases that cannot be detected by $\mathrm{CT}$ or MRI (18).

Type III gastric NETs, in which deep invasion of the gastric wall, lymphatic spread, and distant metastasis are common, should be managed as gastric adenocarcinomas. These tumors consist of mixed endocrine cell types, but ECL cells are still dominant. Lymph node resection should be added to the partial or total gastrectomy (12). In our case series, we observed 11 (64.7\%) type III NETs in 8 males and 3 females whose mean age was 65.1 years. The tumors originated from the antrum in one patient, from the corpus in another one, and from the cardia in the other nine cases. Distal gastrectomy was performed in one patient while 6 patients underwent total gastrectomy. In all of the cases, postoperative histopathological evaluation revealed lymph node metastasis.

Surgery, systemic chemotherapy, or local treatment modalities such as trans-catheter arterial embolization or chemoembolization (TAE, TACE) and radiofrequency ablation may be applied in liver metastases due to gastric NETs. Single lesions considered suitable for removal can be surgically removed $(19,20)$. In our study, liver metastasis was observed in 7 patients, 4 of whom were not suitable for surgery due to poor general condition and received oncological treatment with chemotherapeutic agents. Two patients underwent total radical gastrectomy and metastasectomy while one patient underwent gastrectomy and radiofrequency ablation after surgery.

Carcinoid syndrome (CS), characterized by sudden flushing and edema of the face, increased lacri- mation, bronchospasm, and diarrhea, is rare in gastric NETs. In the literature, the CS frequency in gastric NETs ranges from 0 to $11 \%$. It is more common in patients with type III gastric carcinoid tumors, possibly due to the prevalence of liver metastases. Patients with metastatic disease are more likely to develop CS, in which somatostatin analogues can be used to treat the symptoms (21). In our case series, there was no patient with CS

In conclusion, gastric NETs are categorized into three groups according to mitotic activity and the Ki67 index. Data on serum gastrin levels and endoscopic and radiological work-up are required for this categorization. The treatment approach varies according to the type and stage of the disease but still remains a challenge for clinicians because of its rarity. Further clinical studies are needed to improve the understanding and management of gastric NETs.

\section{Conflict-of-Interest and Financial Disclosure}

The authors declare that they have no conflict of interest to disclose. The authors also declare that they did not receive any financial support for the study.

\section{REFERENCES}

1. Modlin IM, Shapiro MD, Kidd M. Siegfried Oberndorfer: origins and perspectives of carcinoid tumors. Hum Pathol. 2004;35(12):1440-51.

2. Rindi G, Arnold R, Bosman FT, Capella C, Klimstra DS, Klöppel G, et al. Nomenclature and classification of neuroendocrine neoplasms of the digestive system. In: Bosman FT, Carneiro F, Hruban RH, Theise ND (ed.), WHO Classification of Tumours of the Digestive System. Lyon: IARC; 2010:13-14

3. Yao JC, Hassan M, Phan A, Dagohoy C, Leary C, Mares JE, et al. One hundred years after "carcinoid": epidemiology of and prognostic factors for neuroendocrine tumors in 35,825 cases in United States. J Clin Oncol. 2008;26:3063-72.

4. Mougey AM, Adler DG. Neuroendocrine tumors: review and clinical update. Hosp Physician. 2007;51:12-20.

5. Modlin IM, Lye KD, Kidd M. A 5-decade analysis of 13,715 carcinoid tumors. Cancer. 2003;97:934-59.

6. Matsubayashi H, Takagaki S, Otsubo T, Iiri T, Kobayashi Y, Yokota T, et al. Advanced gastric glandular-endocrine cell carcinoma with 1-year survival after gastrectomy. 
Gastric Cancer. 2000;3:226-33.

7. La Rosa S, Inzani F, Vanoli A, Klersy C, Dainese L, Rindi $\mathrm{G}$, et al. Histologic characterization and improved prognostic evaluation of 209 gastric neuroendocrine neoplasms. Hum Pathol. 2011;42:1373-84.

8. Massironi S, Sciola V, Spampatti MP, Peracchi M, Conte D. Gastric carcinoids: between underestimation and overtreatment. World J Gastroenterol. 2009;15:2177-83.

9. Maggard MA, O’Connell JB, Ko CY. Updated population-based review of carcinoid tumors. Ann Surg. 2004;240:117-22.

10. Basuroy R, Srirajaskanthan R, Prachalias A, Quaglia A, Ramage JK. Review article: the investigation and management of gastric neuroendocrine tumours. Aliment Pharmacol Ther. 2014;39(10):1071-84.

11. Merola E, Sbrozzi-Vanni A, Panzuto F, D’Ambra G, Di Giulio E, Pilozzi E, et al. Type I gastric carcinoids: a prospective study on endoscopic management and recurrence rate. Neuroendocrinology. 2012;95(3):207-13.

12. Delle Fave G, Kwekkeboom DJ, van Cutsem E, Rindi G, Kos-Kudla B, Knigge U, et al. ENETS Consensus Guidelines for the management of patients with gastroduodenal neoplasms. Neuroendocrinology. 2012;95(2):74-87.

13. Hosokawa O, Kaizaki Y, Hattori M, Douden K, Hayashi $\mathrm{H}$, Morishita $\mathrm{M}$, et al. Long-term follow up of patients with multiple gastric carcinoids associated with type A gastritis. Gastric Cancer. 2005;8(1):42-6.

14. Sato Y, Imamura H, Kaizaki Y, Koizumi W, Ishido K, Kurahara K, et al. Management and clinical outcomes of type I gastric carcinoid patients: retrospective, multicenter study in Japan. Dig Endosc. 2014;26(3):377-84.
15. Ravizza D, Fiori G, Trovato C, Fazio N, Bonomo G, Luca $\mathrm{F}$, et al. Long-term endoscopic and clinical follow-up of untreated type 1 gastric neuroendocrine tumours. Dig Liver Dis. 2007;39(6):537-43.

16. Ozao-Choy J, Buch K, Strauchen JA, Warner RR, Divino CM. Laparoscopic antrectomy for the treatment of type I gastric carcinoid tumors. J Surg Res. 2010;162(1):22-5.

17. Gladdy RA, Strong VE, Coit D, Allen PJ, Gerdes H, Shia $J$, et al. Defining surgical indications for type I gastric carcinoid tumor. Ann Surg Oncol. 2009;16:3154-60.

18. Nikou GC, Toubanakis C, Nikolaou P, Giannatou E, Marinou K, Safioleas M, et al. Gastrinomas associated with MEN-1 syndrome: new insights for the diagnosis and management in a series of 11 patients. Hepatogastroenterology. 2005;52(66):1668-76.

19. Pavel M, Baudin E, Couvelard A, Krenning E, Öberg K, Steinmüller T, et al. ENETS Consensus Guidelines for the management of patients with liver and other distant metastases from neuroendocrine neoplasms of foregut, midgut, hindgut, and unknown primary. Neuroendocrinology. 2012;95(2):157-76.

20. Vogl TJ, Naguib NN, Zangos S, Eichler K, Hedayati A, Nour-Eldin NE. Liver metastases of neuroendocrine carcinomas: interventional treatment via transarterial embolization, chemoembolization and thermal ablation. Eur J Radiol. 2009;72:517-28.

21. Wolin EM. The expanding role of somatostatin analogues in the management of neuroendocrine tumors. Gastrointest Cancer Res. 2012;5(5):161-8. 